\title{
APPLICATION OF THE PLACKETT-BURMAN DESIGN TO DETERMINE THE MAIN FACTORS AFFECTING THE ANTI-OXIDATIVE ACTIVITY OF GOAT'S MILK CASEIN HYDROLYZED BY ALCALASE AND PAPAIN
}

\author{
Guowei Shu ${ }^{1}$, Sha Mei ${ }^{1 凶}$, Qian Zhang ${ }^{1}$, Ni Xin² ${ }^{2}$ He Chen $^{1}$ \\ ${ }^{1}$ School of Food and Biological Engineering, Shaanxi University of Science and Technology \\ Xi'an, 710021, China \\ ${ }^{2}$ Department of Research and Development, Xi'an Baiyue Goat Milk Corp. \\ Xi'an, 710089, China
}

\begin{abstract}
Background. Antioxidant peptides can scavenge excessive free radicals produced by the metabolism, maintain a free radical balance and prevent aging and disease. Therefore, finding natural resources with strong antioxidant activity has become a new focus for research.

Material and methods. Single-factor experiments were used to investigate the effects of various factors (hydrolysis temperature, $\mathrm{pH}$, substrate concentration, enzyme to substrate ratio $(E / S)$, ratio of compound protease $\left(E_{\text {Alcalase }} / E_{\text {papain }}\right)$ and time on the preparation of antioxidant peptides by compound protease (Alcalase and papain) hydrolysis of goat's milk casein. Then, a Plackett-Burman design was used to determine the significant factors for the preparation of antioxidant peptides by hydrolysis of goat's milk casein with compound protease.

Results. The results of the single-factor experiments indicated that the highest anti-oxidative activity of peptides would be obtained at a hydrolysis temperature of $55^{\circ} \mathrm{C}$, a pH of 7.5 , a substrate concentration of $3.0 \%$, an $E / S$ of $4.0 \%$, a ratio of compound protease of $1 / 3$ and a hydrolysis time of $180 \mathrm{~min}$.

Conclusion. The main factors affecting the activity of anti-oxidative peptides hydrolyzed from goat's milk casein with compound protease were determined by Plackett-Burman design and the results showed that temperature, $E / S$ ratio and the ratio of compound protease had significant influences on the production of antioxidant peptides. This could provide a basis and reference for further optimization.
\end{abstract}

Keywords: antioxidant peptides, goat's milk casein, Plackett-Burman design, compound protease

\section{INTRODUCTION}

Free radicals are produced in all metabolic processes, under the influence of the environment. Healthy human cells, organs and tissues maintain the balance of free radical production and clearance through their own antioxidant defense system with antioxidant enzymes under normal physiological conditions.

The work was partly supported by the key project of the Science and Technology Department of Shaanxi Province (no. 2018ZDXM-NY-085), the Science and Technology Project of Xianyang city (no. 2017K02-69) and the Collaborative Innovation Project of Shaanxi Province (no. 2017XT-17).

『meisha419@163.com 
Therefore, excessive free radicals are cleared to avoid the occurrence of the various chronic diseases which they cause (Chang et al., 2015). However, when the human body is subject to aging or disease, this balance is destroyed, and excessive accumulation of free radicals results (Pan et al., 2016). This increase in levels of free radicals can damage the structure of biomolecules, modify their function, disrupt cellular functions and even cause cell death, and also increases health problems such as cancer, arteriosclerosis, aging and cardiovascular diseases (Kehrer et al., 2015). Therefore, additional antioxidants are needed to eliminate the accumulation of free radicals and reduce the harm caused by free radicals to the human body.

Bioactive peptides have been widely studied in recent years because of their diversity of activity and functionality (Tavano et al., 2018). Antioxidant peptides are biologically active peptides with a variety of biological effects, the most important of which is antioxidant activity (Sila et al., 2016). Antioxidant peptides protect the mitochondria and cell structures and maintain their normal functions by removing excess free radicals, inhibiting lipid peroxidation, binding metal ions and providing hydrogen protons (Nimse et al., 2015). At present, some chemically synthesized antioxidants are toxic and endanger human health. Therefore, the development of safe, healthy and highly effective natural antioxidants has become a hot topic for research (Bougatef et al., 2010). Protein hydrolysis by protease can release antioxidant peptides, and peptides obtained in this way are safe, non-toxic, and have strong antioxidant activity. This also has broad research potential for biology, medical and food science (Shanmugam et al., 2015).

The protein content of goat's milk is high, the biological value of which can be as high as $85 \%$. The protein and fat characteristics of goat's milk are closer to human breast milk than cow's milk, which makes it more suitable for people to drink (Atanasova and Ivanova, 2010). The goat's milk protein clot is fine and soft, containing little or no $\alpha \mathrm{S} 1$ casein. Therefore, it is almost free from allergic risks and is conducive to human digestion and absorption. Goat's milk has a higher mineral and vitamin content than cow's milk and is rich in epithelial factors and many other active factors. (Ahmed et al., 2010; Gobba et al., 2014). Bioactive peptides derived from cow's milk have been widely studied, but the study of peptides from goat's milk is still limited.

In this paper, the effect of several factors (temperature, $\mathrm{pH}, E / S$ ratio, substrate concentration, the ratio of compound protease and time) on the anti-oxidative activity and degree of hydrolysis (DH) in goat's milk casein after hydrolysis by compound enzymes was studied by a single factor. Furthermore, screening the main factors affecting the antioxidant peptides from goat's milk casein with compound enzyme hydrolysis by Plackett-Burman design was carried out, and could provide the basis for further research.

\section{MATERIAL AND METHODS}

Materials. Goat's milk powder was supplied from Xi'an Baiyue Goat Milk Corp., Ltd. (Shaanxi, China). Alcalase, papain, DPPH, 3-(2-pyridyl)-5,6-bis (4-phenylsulphonic acid)-1,2,4-triazine (ferrozine) and Tris-HCl were purchased form Sigma-Aldrich (St. Louis, MO, USA) and all other reagents used in this study were analytical grade chemicals.

Preparation of goat's milk casein. Goat's milk powder was mixed with distilled water in the proportion $1: 8(\mathrm{w} / \mathrm{v})$, and then remove fat from the milk by centrifuging at $5000 \mathrm{r} / \mathrm{min}$ for $15 \mathrm{~min}$. Then the skimmed goat's milk was placed in a water bath heated to a constant temperature of $45^{\circ} \mathrm{C}$, then adjusted to $\mathrm{pH} 4.6$, using $1 \mathrm{~mol} / \mathrm{L} \mathrm{HCl}$ added by drops to cause the goat's milk casein to form a precipitate. The goat's milk casein was separated by centrifugation at $6500 \mathrm{r} / \mathrm{min}$ for $15 \mathrm{~min}$. The supernatant was discarded, then the goat's milk casein precipitate was freeze-dried.

Preparation of enzymatic hydrolysates. Frozen casein was mixed with distilled water at a ratio of 2:100 (w/v) with a compound enzyme/substrate ratio of 1:100 (w/w). The hydrolysis temperature and $\mathrm{pH}$ were adjusted to the optimal values of $55^{\circ} \mathrm{C}$ and 7.5 respectively. During the reaction, the hydrolysis $\mathrm{pH}$ was maintained at the prescribed value by adding $0.1 \mathrm{M}$ sodium hydroxide continuously at regular time intervals and a $4 \mathrm{ml}$ sample was obtained. Then, hydrolysis was terminated by heating the mixture in a $95^{\circ} \mathrm{C}$ water bath for 15 minutes to ensure that the enzyme was 
denatured. The $\mathrm{pH}$ was adjusted to 4.0 and the hydrolysate was centrifuged at $6500 \mathrm{r} / \mathrm{min}$ for 15 minutes, and the supernatant was collected. Then, having adjusted the $\mathrm{pH}$ to 8.0 , the hydrolysate was centrifuged at $6500 \mathrm{r} / \mathrm{min}$ for 15 minutes again and the supernatant was obtained to determine anti-oxidative activity by UV spectrophotometer.

Measurement of protein hydrolysis. The $\mathrm{pH}$-State (Adler-Nissen, 1986) method was used to determine the degree of protein hydrolysis. In the casein hydrolysis process, the hydrolysis $\mathrm{pH}$ was maintained by adding $0.1 \mathrm{M} \mathrm{NaOH}$ continuously to obtain the specified value. Alkali consumption was recorded every 30 minutes for 6 hours. The DH of the protein was calculated according to following equation:

$$
\mathrm{DH}, \%=\left[\left(B \times M_{b}\right) /\left(\alpha \times M_{p} \times h_{\mathrm{tot}}\right)\right] \times 100 \%
$$

where:

$B$ - the volume of $\mathrm{NaOH}, \mathrm{mL}$,

$M_{b}$ - the concentration of $0.1 \mathrm{M} \mathrm{NaOH}$,

$\alpha-$ the degree of dissociation of $\alpha$-amino $(\alpha=$ 0.44 ),

$M_{p}$ - the quality of protein,

$h_{\text {tot }}$ - the total number of peptide bonds in proteins is $8.2 \mathrm{mmol} / \mathrm{g}$.

Measurement of DPPH radical scavenging activity. DPPH free radical scavenging activity was determined according to the method of (Wu et al., 2003). $2 \mathrm{ml}$ of the hydrolysate sample was mixed with $2 \mathrm{ml}$ of 0.1 $\mathrm{mM}$ DPPH in $95 \%$ ethanol. The mixture was shaken well and reacted at room temperature for 30 minutes. Then, absorbance was measured under a wavelength of $517 \mathrm{~nm}$. The DPPH radical scavenging activity was calculated by the following equation:

$$
\begin{gathered}
\text { DPPH radical scavenging activity, } \%= \\
=\left[1-\left(A_{1}-A_{2}\right) / A_{0}\right] \times 100 \%
\end{gathered}
$$

where:

$A_{1}$ - the absorbance of DPPH solution by the sample,

$A_{0}$ - the absorbance of DPPH-ethanol solution by the control,

$A_{2}$ - the absorbance of the sample added to $95 \%$ ethanol without DPPH solution.
Determination of metal-chelating activity. The method of (Decker and Welch, 1990) was used to determine the ability of chelating pro-oxidative $\mathrm{Fe}^{2+}$ of casein hydrolysates. $1 \mathrm{~mL}$ of hydrolysate sample was mixed with $3.7 \mathrm{~mL}$ of distilled water in a tube, and 0.1 $\mathrm{mL}$ of $2 \mathrm{mM} \mathrm{FeCl}_{2}$ solution and $0.2 \mathrm{~mL}$ of $5 \mathrm{mM}$ ferrozine solution were added in sequence. The mixture was thoroughly mixed and reacted at room temperature for 20 minutes. Then, measured the absorbance at $562 \mathrm{~nm}$. Chelating activity was determined by the following equation:

Chelating activity, $\%=\left[1-\left(A_{1} / A_{2}\right)\right] \times 100 \%$

where:

$A_{1}$ - the absorbance of the sample,

$A_{2}$ - the absorbance of the control (distilled water).

Determination of superoxide radical scavenging activity. The method of (Marklund and Marklund, 1974) was applied to determine superoxide radical scavenging activity. $0.2 \mathrm{~mL}$ of the hydrolysate sample was mixed with $5.7 \mathrm{~mL}$ of $50 \mathrm{mM}$ Tris-HCl-EDTA buffer $(\mathrm{pH}=8.2$, EDTA concentration of $1 \mathrm{mM})$ in a tube. Next, $0.1 \mathrm{~mL}$ of $5 \mathrm{mM}$ pyrogallol was added to the mixtures and mixed quickly. Then, the mixtures were measured at the absorbance of $325 \mathrm{~nm}$ and the mixtures recorded every $30 \mathrm{~s}$. The reaction was complete after $5 \mathrm{~min}$. The capability for scavenging superoxide anion radicals was quantified according to the following equation:

Scavenging activity of $\mathrm{O}^{2-}, \%=$ $=\left[\left(A_{1} / \mathrm{min}-A_{2} / \mathrm{min}\right) /\left(A_{1} / \mathrm{min}\right)\right] \times 100 \%$

where:

$$
\begin{array}{r}
A_{1} / \text { min - the absorbance per minute of the con- } \\
\text { trol solution containing pyrogallol and } \\
\text { a buffer, }
\end{array}
$$

Plackett-Burman design. A Plackett-Burman design was used to evaluate the effects of the six factors (temperature, $\mathrm{pH}$, substrate concentration, $E / S$, ratio of compound protease and time) on DPPH free radical scavenging rate, chelated iron ion capacity and superoxide anion clearance rate. Each factor was fixed at two levels based on the results of the single-factor experiments; the higher level was 1.25 times the lower level. 
Table 1. The factor level coding table of production peptide conditions by complex enzymes

\begin{tabular}{clcc}
\hline \multirow{2}{*}{$\begin{array}{l}\text { Vari- } \\
\text { ables }\end{array}$} & \multicolumn{1}{c}{ Factor } & $\begin{array}{c}\text { Lower } \\
\text { level }\end{array}$ & $\begin{array}{c}\text { Higher } \\
\text { level }\end{array}$ \\
\cline { 3 - 4 } & & $(-1)$ & $(+1)$ \\
\hline $\mathrm{A}$ & temperature, ${ }^{\circ} \mathrm{C}$ & 55 & 69 \\
$\mathrm{~B}$ & $\mathrm{pH}$ & 7.5 & 9 \\
$\mathrm{C}$ & substrate concentration, $\%$ & 3 & 4 \\
$\mathrm{D}$ & $\begin{array}{l}\text { E/S, \% } \\
\mathrm{E}\end{array} \quad \begin{array}{l}\text { ratio of compound protease } \\
\quad \mu \mathrm{L}: \mathrm{mg}\end{array}$ & $1: 3$ & $5: 12$ \\
$\mathrm{~F}$ & time, min & 180 & 225 \\
\hline
\end{tabular}

Statistical analysis. The Design-Expert (Version, 8.0.6) software was used to analyze experimental data to identify important factors and their corresponding coefficients. Therefore, squares, $F$-values, $p$-values, and confidence intervals $(\mathrm{CI})$ were evaluated to analyze the effects of various factors on the activity of anti-oxidative peptides.

\section{RESULTS AND DISCUSSION}

\section{Effect of temperature on the degree of hydrolysis of goat's milk casein and evaluation of antioxidant activity}

The selected substrate concentration was $2 \%$, the ratio of compound protease $\left(E_{\text {Alcalase }} / E_{\text {papain }}\right)$ was $1: 1, E / S$ was $1 \%, \mathrm{pH}=7$, under the condition of enzymatic hydrolysis degree of $2.5 \mathrm{~h}$, the result was shown in Figure 1.

As can be seen from Figure 1, DH increased with rising temperature, reached a maximum value of $15.09 \%$ at $55^{\circ} \mathrm{C}$, then decreased as temperature increased further. DPPH radical scavenging activity, $\mathrm{Fe}^{2+}$ chelation activity and superoxide radical scavenging activity also reached their maximum values at $55^{\circ} \mathrm{C}$, which were $63.69 \%, 90.84 \%$ and $45.06 \%$ respectively.

According to Zhong et al. (2009), the optimum temperature for papain hydrolysis of soybean protein was $55^{\circ} \mathrm{C}$, because the enzyme was more stable in the range of $50-60^{\circ} \mathrm{C}$. When the temperature reached at $60^{\circ} \mathrm{C}$, enzyme activity fell. High temperatures can destroy the structure of the enzyme, making it inactive, and thus antioxidant activity will decrease (Daniel

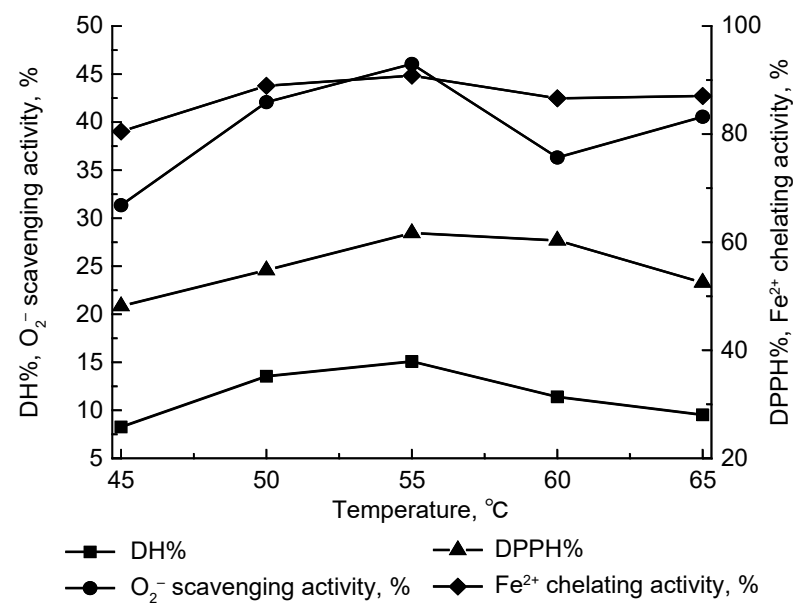

Fig. 1. Effect of temperature on anti-oxidative activity

et al., 2008). The optimum temperature for hydrolysis of the single protease Alcalase was also $55^{\circ} \mathrm{C}$ (Shu et al., 2016), which indicated that, at this temperature, it had the highest ability to degrade casein in goat's milk, and that the antioxidant activity of peptides hydrolyzed by compound protease was relatively high. Therefore, $55^{\circ} \mathrm{C}$ was chosen as the optimum hydrolysis temperature.

\section{Effect of $\mathrm{pH}$ on the degree of hydrolysis of goat's milk casein and evaluation of antioxidant activity}

The selected concentration of substrate was $2 \%$, $E_{\text {Alcalase }} / E_{\text {papain }}$ was $1: 1, E / S$ was $1 \%$, temperature was $55^{\circ} \mathrm{C}$, and the hydrolysis time was $2.5 \mathrm{~h}$. The results are shown in Figure 2.

In the process of enzymatic hydrolysis, $\mathrm{pH}$ was one of the most important factors in determining the activity of the enzyme (Teng et al., 2011). Enzyme activity affects the degree of enzymatic hydrolysis in a strongly acidic or alkaline environment.

It can be seen from Figure 2 that the maximum value of $\mathrm{DH}$ was $16.59 \%$ at $\mathrm{pH} 7.5$, and then this value decreased as the $\mathrm{pH}$ increased. DPPH radical scavenging activity, $\mathrm{Fe}^{2+}$ chelation activity and superoxide radical scavenging activity reached their maximum values at $\mathrm{pH} 7.5$, which were $64.98 \%, 93.71 \%$, and $45.24 \%$ respectively.

The maximum value of casein hydrolyzed by single enzyme Alclases was found at pH 8.9 (Shu et al., 


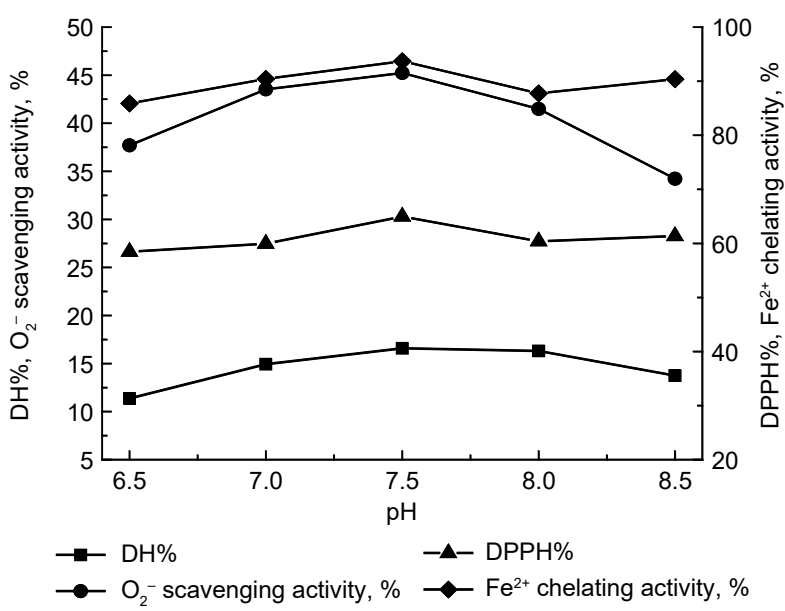

Fig. 2. Effect of $\mathrm{pH}$ on antioxidant activity

2017). This was because the optimum range of Alcalase was probably between 7 and 9 and the optimum $\mathrm{pH}$ value of papain was between 6 and 8 (Bezerra et al., 2013). When $\mathrm{pH}=7.5$, the substrate bonded strongly with the two proteases, at the same time, the optimum $\mathrm{pH}$ conditions of the two proteases was not exceeded. Therefore, $\mathrm{pH} 7.5$ was the optimum condition, which was not only favorable for hydrolysis, but also promoted high levels of activity of antioxidant peptides.

\section{Effect of substrate concentration on the degree of hydrolysis of goat's milk casein and evaluation of antioxidant activity}

The selected temperature was $55^{\circ} \mathrm{C}, E / S$ was $1 \%$, $\mathrm{pH}=7.5, E_{\text {Alcalase }} / E_{\text {papain }}$ was $1: 1$, the time was $2.5 \mathrm{~h}$. The results are shown in Figure 3.

From the results shown in Figure 3, it can be stated that DPPH radical scavenging activity, the capacity of $\mathrm{Fe}^{2+}$ chelation activity ions, superoxide radical scavenging activity and $\mathrm{DH}$ were basically the same, with maximum values at a substrate concentration of $3 \%$, which were $66.74 \%, 92.07 \%$ and $47.21 \%$ respectively.

When the substrate concentration was less than $3 \%$, the activity of anti-oxidative peptides increased rapidly with increasing substrate concentration, which is in accordance with the Michaelis-Menten equation (Gooch et al., 2011). Then, the activity of anti-oxidative activity began to decrease in the enzymatic hydrolysate as the substrate concentration further increased.

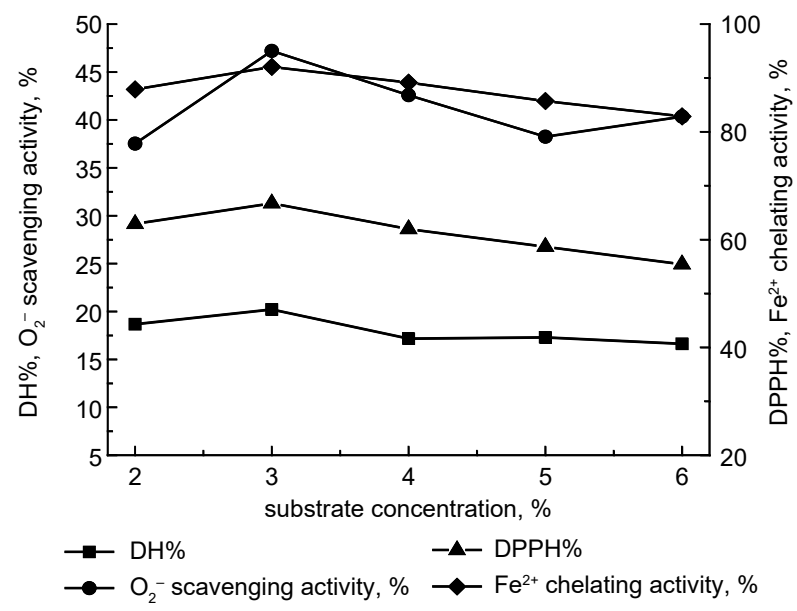

Fig. 3. Effect of substrate concentration on antioxidant activity

Because excessive substrate concentration was not beneficial to the full dispersion of protein, it reduced the opportunity for the enzyme to contact with substrate. Otherwise, excessive substrate concentration would reduce water activity and inhibit enzyme activity (Luo et al., 2011). The concentration of substrate within a certain range did not only have advantages for the hydrolysis reaction, but was also conducive to the production of antioxidant peptides. Therefore, a substrate concentration of $3 \%$ was selected.

\section{Effect of E/S ratio on the degree of hydrolysis of goat's milk casein and evaluation of antioxidant activity}

The selected temperature was $55^{\circ} \mathrm{C}$, the concentration of substrate was $3 \%, \mathrm{pH}=7.5, E_{\text {Alcalase }} / E_{\text {papain }}$ was $1: 1$, the hydrolysis time was $2.5 \mathrm{~h}$ and the $E / S$ varied as shown in Figure 4.

As can be seen from the results in Figure 4, as $E / S$ increased, the initial reaction rate of the system was fast, so most of the protein degraded into a peptide in a short period of time. When the level of protein was reduced to a certain level, the probability of the enzyme interacting with the protein was greatly reduced. Therefore, the increase in DH became steadier. Because at this time the substrate of protease was a peptide, the hydrolytic peptide also caused a slow increase in hydrolysis, but this increase was very small (Fereidoon et al., 2007). The antioxidant activity began to 


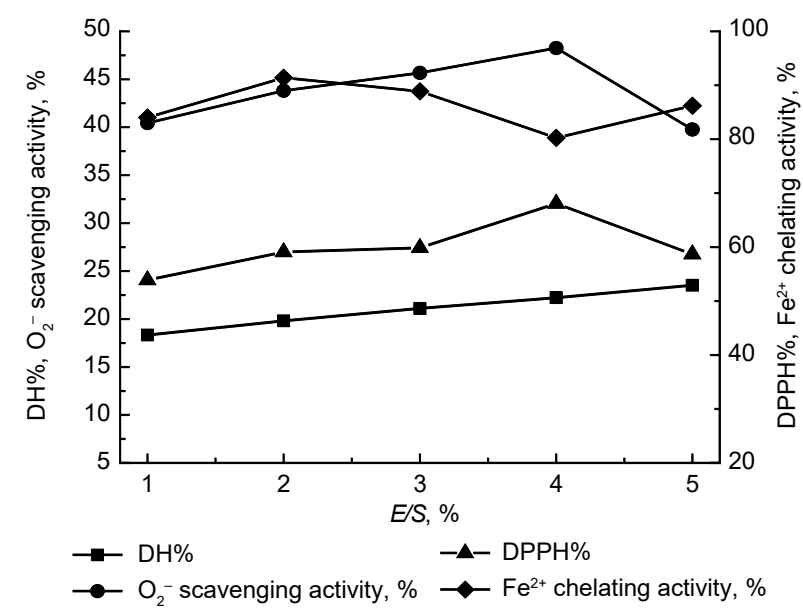

Fig. 4. Effect of $E / S$ ratio on antioxidant activity

gradually increase with the amount of enzyme added, but when the amount of enzyme addition reached a certain level, it decreased. When the $E / S$ was $4 \%$, DPPH free radical scavenging rate and superoxide radical scavenging activity reached a maximum of $69.07 \%$ and $47.25 \%$ respectively. Chelating iron ion ability reached a maximum value of $91.39 \%$ at an $E / S$ of $3 \%$. Therefore, the optimum condition for enzyme addition was $4 \%$.

\section{Effect of the ratio of compound protease on the degree of hydrolysis of goat's milk casein and evaluation of antioxidant activity}

The selected temperature was $55^{\circ} \mathrm{C}$, the concentration of substrate was $3 \%, \mathrm{pH}=7.5$, the $E / S$ was $4 \%$. The time was $2.5 \mathrm{~h}$ and the ratio of compound protease varied as shown in Figure 5.

From Figure 5, it can be demonstrated that when $E_{\text {Alcalase }} / E_{\text {papain }}$ was $1: 3$, antioxidant activity reached its maximum value, which indicated that, in the process of hydrolysis of the complex enzyme, more papain can increase the DH of the enzymatic hydrolysate and produce more polypeptides with antioxidant activity. However, if the content of papain is too high, the substrate is excessively digested. If the polypeptide with antioxidant activity is digested into a short peptide, it loses its antioxidant activity (Waglay and Karboune, 2016).

Compared to the results of Shu et al. (2015), the degree of hydrolysis of complex proteases is higher

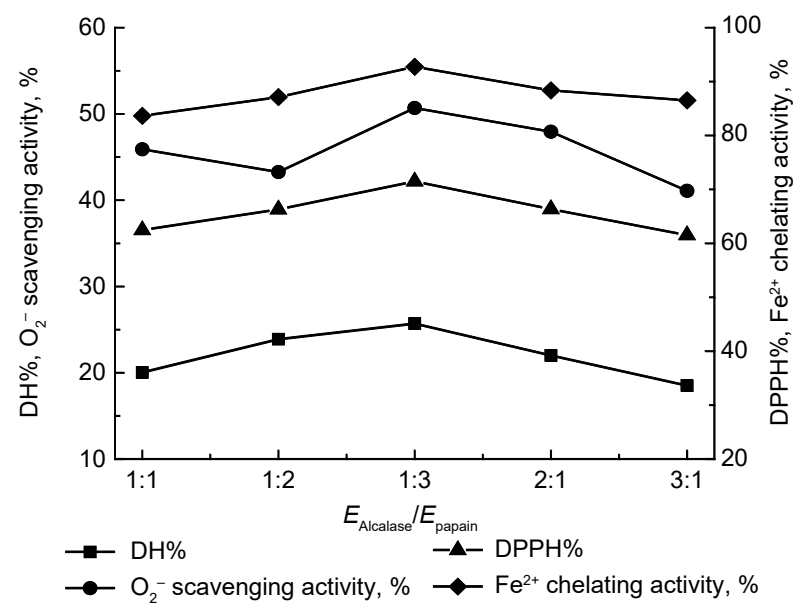

Fig. 5. Effect of the ratio of compound protease on antioxidant activity

than single proteases. This was because different enzymes have different cleavage sites during enzymatic hydrolysis, and the ability of a single enzyme to hydrolyze is limited. Therefore, different enzymes can complement each other in the process of complex enzyme hydrolysis and create conditions more favorable to the production of antioxidant peptides (Tavano et al., 2013).

\section{Effect of time on the degree of hydrolysis of goat's milk casein and evaluation of antioxidant activity}

The selected temperature was $55^{\circ} \mathrm{C}$, the concentration of substrate was $3 \%, \mathrm{pH}=7.5, E_{\text {Alcalase }} / E_{\text {papain }}$ was $1: 3$, the $E / S$ was $4 \%$. The results are shown in Figure 6.

As can be seen from Figure 6, at first, the DH increased as time increased. When a certain time was reached, the increase in DH slowed. DPPH radical scavenging activity and superoxide radical scavenging activity were maximized at $180 \mathrm{~min}$ and the values were $72.23 \%$ and $52.88 \%$ respectively. $\mathrm{Fe}^{2+}$ chelation activity achieved a maximum value of $91.24 \%$ at 150 min.

It may be that, as the duration of enzymatic hydrolysis increased and DH gradually increased, antioxidant peptides were hydrolyzed excessively, which increased the content of short peptides and amino acids in the solution and had an inhibitory effect, which led to a decreasing rate of DPPH radical scavenging. 


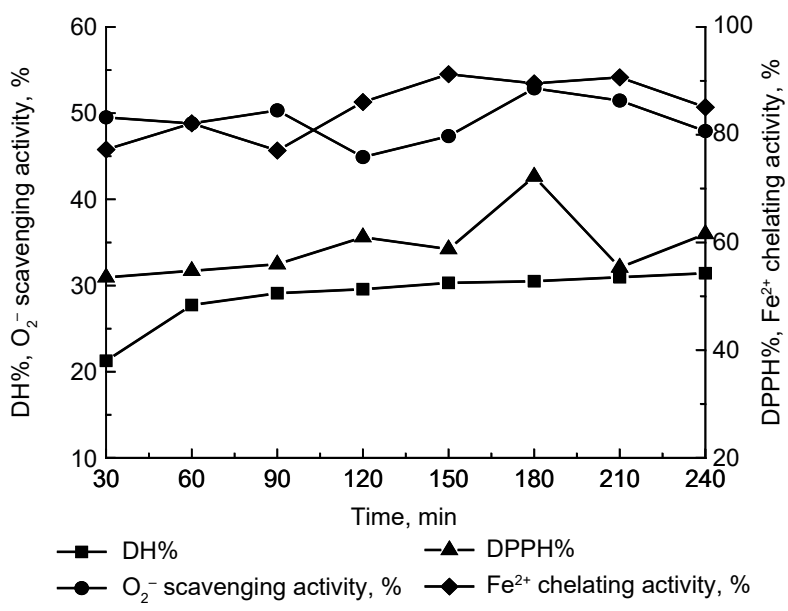

Fig. 6. Effect of time on anti-oxidative peptides activity

After this, the quantity of short peptides in the solution did not change rapidly, which made the DH change stable (Zhang et al., 2012). Therefore, considering the results of the experiment, $180 \mathrm{~min}$ was selected as the optimum hydrolysis time.

\section{Plackett-Burman design for determining the main factors}

According to the previous results, the Plackett-Burman design and results are shown in Table 2. The $R_{1}$ (\%) represents DPPH radical-scavenging activity, $R_{2}$ (\%) represents $\mathrm{Fe}^{2+}$ chelation activity and $R_{3}(\%)$ represents superoxide radical scavenging activity.
According to the data presented in Table 3, analysis of variance, a $p$-value of 0.0223 showed that the model was significant. In the ANOVA, a $p$-value less than 0.0500 indicated that the results were significant. In the analysis of these 5 factors, the $p$-value of temperature (A), the $E / S(\mathrm{E})$ and the ratio of compound protease $(\mathrm{F})$ were $0.011,0.014$ and 0.0176 respectively, indicating that these factors had a great influence on DPPH radical-scavenging activity in the experiment. The relative importance of the variables on the free radical scavenging rate of DPPH was as follows: A > $\mathrm{E}>\mathrm{F}>\mathrm{G}>\mathrm{B}>\mathrm{C}$. Therefore temperature (A), the $E / S$ ratio (E) and ratio of compound protease (F) had a significant effect on DPPH radical scavenging activity $\left(R_{1}\right)$.

From Table 4, the model can be shown to be significant by the $p$-value of 0.0262 . Analysis of these factors found that the relative importance of the variables was as follows: $\mathrm{G}>\mathrm{A}>\mathrm{E}>\mathrm{F}>\mathrm{B}>\mathrm{C}$. Among the above factors, time $(\mathrm{G})(p=0.146)$, temperature (A) $(p=0.0186)$, and the $E / S$ ratio (E) $(p=0.0189)$ were significant, indicating that these three factors had a greater influence on the $\mathrm{Fe}^{2+}$ chelation activity in the experiment $\left(R_{2}\right)$.

From Table 5, the square sum of the model was 108.17 and the $p$-value was 0.0070 , which demonstrates that the experimental model was significant. At the same time, time (G) $(p=0.0032)$, ratio of compound protease $(\mathrm{F})(p=0.0069)$ and substrate concentration (E) $(p=0.0046)$ were all less than 0.011, showing that these were very significant factors. Therefore,

Table 2. The design and results of the Plackett-Burman design for peptide-producing anti-oxidative peptides

\begin{tabular}{clllllllllll}
\hline Run & $\mathrm{A}$ & $\mathrm{B}$ & $\mathrm{C}$ & $\mathrm{D}$ & $\mathrm{E}$ & $\mathrm{F}$ & $\mathrm{G}$ & $R_{1}, \%$ & $R_{2}, \%$ & $\mathrm{R}_{3}, \%$ \\
\hline 1 & 55 & 7.5 & 4 & 1 & 4 & $1: 3$ & 225 & 61.02 & 86.32 & 46.39 \\
2 & 55 & 9 & 3 & -1 & 5 & $5: 12$ & 225 & 63.57 & 89.48 & 42.09 \\
3 & 55 & 9 & 4 & -1 & 4 & $1: 3$ & 180 & 64.03 & 90.69 & 43.16 \\
4 & 55 & 7.5 & 3 & 1 & 5 & $5: 12$ & 180 & 65.61 & 92.01 & 39.47 \\
5 & 69 & 7.5 & 3 & -1 & 4 & $1: 3$ & 225 & 59.67 & 89.69 & 46.86 \\
6 & 69 & 9 & 3 & 1 & 4 & $1: 3$ & 180 & 59.16 & 91.85 & 38.48 \\
7 & 69 & 7.5 & 4 & -1 & 5 & $5: 12$ & 180 & 61.05 & 92.12 & 42.48 \\
8 & 69 & 9 & 4 & 1 & 5 & $5: 12$ & 225 & 62.73 & 92.01 & 50.14 \\
\hline
\end{tabular}


Table 3. The ANOVA of DPPH free radical scavenging activity

\begin{tabular}{crrrrr}
\hline Source & \multicolumn{1}{c}{ SS } & DF & \multicolumn{1}{c}{ MS } & $F$-value & $p$-value \\
\hline Model & 35.42 & 6 & 5.90 & 1180.50 & 0.0223 \\
A & 16.88 & 1 & 16.88 & 3375.61 & 0.0110 \\
B & 0.57 & 1 & 0.57 & 114.49 & 0.0593 \\
C & 0.08 & 1 & 0.08 & 16.81 & 0.1523 \\
E & 10.31 & 1 & 10.31 & 2061.16 & 0.0140 \\
F & 6.55 & 1 & 6.55 & 1310.44 & 0.0176 \\
G & 1.02 & 1 & 1.02 & 204.49 & 0.0444 \\
\hline
\end{tabular}

Table 4. The ANOVA of metal-chelating effects

\begin{tabular}{crrrrr}
\hline Source & \multicolumn{1}{c}{ SS } & DF & \multicolumn{1}{c}{ MS } & $F$-value & $p$-value \\
\hline Model & 28.20 & 6 & 4.70 & 852.70 & 0.0262 \\
A & 6.43 & 1 & 6.43 & 1165.74 & 0.0186 \\
B & 1.89 & 1 & 1.89 & 343.13 & 0.0343 \\
C & 0.45 & 1 & 0.45 & 81.00 & 0.0704 \\
E & 6.25 & 1 & 6.25 & 1133.44 & 0.0189 \\
F & 2.68 & 1 & 2.68 & 486.10 & 0.0289 \\
G & 10.51 & 1 & 10.51 & 1906.78 & 0.0146 \\
\hline
\end{tabular}

Table 5. The ANOVA of superoxide anion radical scavenging activity

\begin{tabular}{crcrrr}
\hline Source & \multicolumn{1}{c}{ SS } & DF & \multicolumn{1}{c}{ MS } & $F$-value & $p$-value \\
\hline Model & 108.17 & 6 & 18.03 & 11919.79 & 0.0070 \\
A & 5.87 & 1 & 5.87 & 3877.89 & 0.0102 \\
B & 0.22 & 1 & 0.22 & 146.19 & 0.0525 \\
C & 29.15 & 1 & 29.15 & 19270.49 & 0.0046 \\
E & 0.06 & 1 & 0.06 & 41.66 & 0.0979 \\
F & 12.98 & 1 & 12.98 & 8581.50 & 0.0069 \\
G & 59.90 & 1 & 59.90 & 39601 & 0.0032 \\
\hline
\end{tabular}

time $(\mathrm{G})$, ratio of compound protease $(\mathrm{F})$ and substrate concentration (E) had a positive effect on superoxide radical scavenging activity $\left(R_{3}\right)$.

Through the analysis of variance of the three response values, the three most significant factors in DPPH radical scavenging activity were temperature, $E / S$ and the ratio of compound protease. The three most significant factors affecting $\mathrm{Fe}^{2+}$ chelation activity were time, temperature and $E / S$. The most significant three factors for superoxide radical scavenging activity were time, ratio of compound protease and substrate concentration. It can be seen from the experimental results that the capacity to chelate iron already very high, it was difficult to optimize. According to the result of the single-factor experiment and the $\mathrm{P}-\mathrm{B}$ design, the optimized space of the superoxide radical scavenging activity is smaller than the DPPH radical-scavenging activity. So, the main result of this experiment was to improve DPPH radical-scavenging activity. The results of $\mathrm{Fe}^{2+}$ chelation activity and superoxide radical scavenging activity were supplemented by follow-up optimization. Therefore, based on the results of the above analysis, temperature, $E / S$, and the ratio of compound protease have the effect of enhancing anti-oxidative activity and are selected as the main factors for further testing.

DPPH is a stable free radical, and the DPPH radicalscavenging activity is currently considered one of the important indicators of whether a given compound has antioxidant capacity (Centenaro et al., 2011). Guerard et al. (2007) optimized free radical scavenging activity by response surface methodology through three variables; $\mathrm{pH}$, temperature and $E / S$. Thus, it is necessary to optimize the production of anti-oxidative peptides by the compound protease hydrolysis of goat's milk casein. In the present study, the results showed that temperature, $E / S$ and the ratio of compound protease had positive effects on antioxidant activity.

\section{CONCLUSION}

In this study, the effects of temperature, $\mathrm{pH}$, substrate concentration, $E / S$, ratio of compound protease, and hydrolysis time on the anti-oxidative activity of hydrolysates from goat's milk casein by compound protease were researched. Single factor analysis and Plackett-Burman designed tested for the most significant 
Shu, G., Mei, S., Zhang, Q., Xin, N., Chen, H. (2018). Application of the Plackett-Burman design to determine the main factors affecting the anti-oxidative activity of goat's milk casein hydrolyzed by Alcalase and papain. Acta Sci. Pol. Technol. Aliment., 17(3), 257-266. http://dx.doi.org/10.17306/J.AFS.2018.0580

factors affecting the preparation of anti-oxidative peptides by hydrolysis of goat's milk casein with compound protease. The results showed that temperature, $E / S$ and compound protease ratio had significant effects on the enhancement of anti-oxidative activity.

\section{REFERENCES}

Atanasova, J., Ivanova, I. (2010). Antibacterial peptides from goat and sheep milk proteins. Biotechnol. Biotec. Equip., 24(2), 1799-1803. https://doi.org/10.2478/ V10133-010-0049-8

Adler-Nissen, J. (1986). Enzymatic hydrolysis of food proteins. Can. Med. Assoc. J., 172(8), 1783-1785.

Ahmed, A. S., El-Bassiony, T., Elmalt, L. M. (2015). Identification of potent antioxidant bioactive peptides from goat's milk proteins. J. Food. Res. Int., 74, 80-88. https://doi.org/10.1016/j.foodres.2015.04.032

Bougatef, A., Nedjar-Arroume, N., Manni, L. (2010). Purification and identification of novel antioxidant peptides from enzymatic hydrolysates of sardinelle (Sardinella aurita) by-products proteins. Food. Chem., 118(3), 559565. https://doi.org/10.1016/j.foodchem.2009.05.021

Bezerra, V. S., Campos, J. F., Silva, R. A. D. (2013). Biotechnological richness of the northeastern semi-arid region: antioxidant activity of casein hydrolysates from moxotó goat's milk (Capra hircus Linnaeus, 1758) obtained by papain action. Food Sci Technol., Campinas, 33(3), 513-520. http://dx.doi.org/10.1590/ S0101-20612013005000074

Chang, S. K., Ismail, A., Yanagita, T. (2015). Antioxidant peptides purified and identified from the oil palm (Elaeis guineensis Jacq.) kernel protein hydrolysate. Funct. Foods, 14, 63-75. https://doi.org/10.1016/j. jff.2015.01.011

Centenaro, G. S., Mellado, M. S., Prentice-Hernández, C. (2011). Antioxidant activity of protein hydrolysates of fish and chicken bones. Adv. J. Food Sci. Technol., 3(4), 280-288. http://repositorio.furg.br/handle/1/1730

Decker, E. A., Welch, B. (1990). Role of ferritin as a lipid oxidation catalyst in muscle food. J. Agric. Food. Chem., 38(3), 674-677.

Daniel, R. M., Danson, M. J., Eisenthal, R. (2008). The effect of temperature on enzyme activity: new insights and their implications. Extremophiles, 12(1), 51-59. https:// doi.org/10.1007/s00792-007-0089-7

Fereidoon, S., Cesarettin, A. A., Liyanapathirana, C. M. (2007). Antioxidant phytochemicals in hazelnut kernel (Corylus avellana L.) and hazelnut byproducts. J. Agric.
Food Chem., 55(4), 1212-20. https://doi.org/10.1021/ jf062472o

Gobba, C. D., Espejo-Carpio, F. J., Skibsted, L. H. (2014). Antioxidant peptides from goat's milk protein fractions hydrolysed by two commercial proteases. Int. Dairy J., 39(1), 28-40. https://doi.org/10.1016/j. idairyj.2014.03.015

Guerard, F., Sumaya-Martinez, M. T., Laroque, D. (2007). Optimization of free radical scavenging activity by response surface methodology in the hydrolysis of shrimp processing discards. Process. Biochem., 42(11), 14861491. https://doi.org/10.1016/j.procbio.2007.07.016

Gooch, J. W. (2011). Michaelis-Menten equation. In: G. P. Rédei, Encyclopedia of genetics, genomics, proteomics, and informatics (pp. 907-907). Springer.

Kehrer, J. P., Klotz, L.-O. (2015). Free radicals and related reactive species as mediators of tissue injury and disease: implications for health. Crit. Rev. Toxicol., 45(9), 765798. https://doi.org/10.3109/10408444.2015.1074159

Luo, L. H., Sun, J. H., Huang, Q. X. (2011). Optimization of enzymatic hydrolysis conditions parameters for antioxidant capacity of hydrolysates from protein of Tilapia heels. J. Guangxi Univ., 36(3), 389-394.

Marklund, S., Marklund, G. (1974). Involvement of the superoxide anion radical in the autoxidation of pyrogallol and a convenient assay for superoxide dismutase. Eur. J. Biochem., 47(3), 469-474. https://doi. org/10.1111/j.1432-1033.1974.tb03714.x

Nimse, S. B., Pal, D. (2015). Free radicals, natural antioxidants, and their reaction mechanisms J. Rsc. Adv., 5(35), 27986-28006.

Pan, X., Zhao, Y. Q., Hu, F. Y., Wang B. (2016). Preparation and identification of antioxidant peptides from protein hydrolysate of skate (Raja porosa) cartilage. J. Funct. Foods, 25, 220-230. https://doi.org/10.1016/j. jff.2016.06.008

Rizzello, C. G., Tagliazucchi, D., Babini, E., Rutella, G. S., Taneyo Saa, D. L., Gianotti, A. (2016). Bioactive peptides from vegetable food matrices: Research trends and novel biotechnologies for synthesis and recovery. J. Funct. Foods, 27, 549-569. http://dx.doi.org/10.1016/j. jff.2016.09.023

Sila, A., Bougatef, A. (2015). Antioxidant peptides from marine by-products: Isolation, identification and application in food systems. A review. J. Funct. Foods, 21, 10-26. https://doi.org/10.1016/j.jff.2015.11.007

Shanmugam, V. P., Kapila, S., Sonfack, T. K., Kapila R. (2015). Anti-oxidative peptide derived from enzymatic digestion of buffalo casein. Int. Dairy J., 42(42), 1-5. https://doi.org/10.1016/j.idairyj.2014.11.001 
Shu, G., Zhang, B., Zhang, Q. (2016). Effect of temperature, $\mathrm{pH}$, enzyme to substrate ratio, substrate concentration and time on the anti-oxidative activity of hydrolysates from goat's milk casein by alcalase. Acta Univ. Cibin. Ser. E. Food Technol., 20(2). https://doi.org/10.1515/ aucft-2016-0013

Shu, G., Zhang, Q., Chen, H.. Wan, H., Li, H. (2015). Effect of five proteases including alcalase, flavourzyme, papain, proteinase $\mathrm{K}$ and trypsin on antioxidative activities of casein hydrolysate from goat milk. Acta Univ. Cibin. Ser. E. Food Technol., 19(2), 65-74. https://doi. org/10.1515/aucft-2015-0015

Shu, G., Wang, Z., Chen, L. (2017). Enzymolysis technology optimization for production of antioxidant peptides from goat milk casein. Acta Univ. Cibin. Ser. E. Food Technol., 21(1). https://doi.org/10.1515/aucft-2017-0006

Tavano, O. L., Berenguer-Murcia, A., Secundo, F., Fernandez-Lafuente, R. (2018). Biotechnological applications of proteases in food technology. Compr. Rev. Food Sci. Food Safety, 17(2). https://doi.org/10.1111/ $1541-4337.12326$

Tavano, O. L. (2013). Protein hydrolysis using proteases: An important tool for food biotechnology. J. Mol. Catal. B: Enzymatic, 90, 1-11. https://doi.org/10.1016/j. molcatb.2013.01.011
Teng, D., Fang, Y., Song, X. (2011). Optimization of enzymatic hydrolysis parameters for antioxidant capacity of peptide from goat placenta. Food. Bioprod. Process., 89(3), 202-208.

Waglay, A., Karboune, S. (2016). Enzymatic generation of peptides from potato proteins by selected proteases and characterization of their structural properties. Biotechnol. Progr., 32(2), 420-429. https://doi.org/10.1002/ btpr.2245

Wu, H.-C., Chen, H.-M., Shiau, C.-Y. (2003). Free amino acids and peptides as related to antioxidant properties in protein hydrolysates of mackerel (Scomber austriasicus). Food Res. Int., 36(9), 949-957. https://doi. org/10.1016/S0963-9969(03)00104-2

Zhong, Z. S., Chen, Y., Wen, X. L. (2009). Hydrolysis of soybean protein isolate by papain and neutral protease. Modern Food Sci. Technol., 1039-1042, 1079.

Zhang, T., Jiang, B., Miao, M.. Mu, W., Li, Y. (2012). Combined effects of high-pressure and enzymatic treatments on the hydrolysis of chickpea protein isolates and antioxidant activity of the hydrolysates. Food. Chem., 135(3), 904-912 https://doi.org/10.1016/j. foodchem.2012.05.097 